\title{
Responses of fast and slow growth broilers fed all vegetable diets with variable ideal protein profiles
}

\author{
Jorge Luis Bernardon Coneglian ${ }^{1}$, Sergio Luiz Vieira ${ }^{2}$, Josemar Berres ${ }^{1}$, Dimitri Moreira \\ de Freitas ${ }^{1}$
}

1 Programa de Pós-graduação em Zootecnia-UFRGS.

2 Departamento de Zootecnia - UFRGS.

\begin{abstract}
One thousand eight hundred and ninety male broilers of two strain crosses (fast and slow initial growth) were fed different ideal protein profiles in four-phase feed programs: 1 to 7, 8 to 21, 22 to 34 and 35 to 40 days of age. All vegetable, corn-soybean meal feeds were formulated to maintain the Met+Cys:Lys and Thr:Lys relationships at 75 and 65\%, respectively, on true digestible basis. Three ideal protein profiles were used: low, medium and high. From 1 to 21 days of age, half of the birds fed low and high diets were changed to high and low diets, respectively. Birds on the medium diet were kept on the same diet until the end of the study. A $3 \times 2$ (ideal protein profile $\mathrm{x}$ strain cross) factorial design was used for the period from 1 to 21 days and a $5 \times 2$ design thereafter. Carcass and commercial cuts were performed at 34 and 40 days of age to determine corresponding live weight and carcass yields. In general, the fast strain growth was superior in comparison to the low one when live performance and carcass and commercial cuts were evaluated. Live performance was positively affected by the increases in the dietary protein profiles; however, processing yield parameters could not be related with the dietary parameters. The low diets, which have similar protein contents to those used in some integrations, were shown to produce poor responses and, therefore are not recommended for broilers from 1 to 40 days of age. Alternating low and high ideal protein profiles at 21 days could result in similar feed conversions, and therefore, can lead to production cost reduction.
\end{abstract}

Key Words: amino acids, carcass, digestible lysine, performance, strain crosses

\section{Respostas de frangos de corte de crescimento rápido e lento consumindo dietas exclusivamente vegetais com diferentes perfis de proteína ideal}

RESUMO - Mil oitocentos e noventa frangos de corte machos de duas linhagens comerciais (de crescimento inicial rápido e lento) receberam dietas com diferentes perfis de proteína ideal em programas alimentares de quatro fases: 1 a 7; 8 a 21; 22 a 34; e 35 a 40 dias de idade. Dietas exclusivamente vegetais, à base de milho e farelo de soja, foram formuladas de modo a manter as relações Met+Cis:Lis e Ter:Lis em 75 e 65\%, respectivamente, em base digestível verdadeira. Foram utilizados três perfis de proteína ideal: baixo, médio e alto. Aos 21 dias de idade, metade das aves consumindo dieta de perfil baixo passou a receber perfil alto e metade daquelas que receberam perfil alto passaram a receber dieta de perfil baixo. As aves que recebiam dieta de perfil médio permaneceram sem alteração até o final do estudo. Utilizou-se esquema fatorial $3 \times 2$ (perfil de proteína ideal $\times$ linhagem) para o período de 1 a 21 dias e $5 \times 2$ para o período de 21 a 40 dias de idade. Além das respostas de desempenho zootécnico, foram realizados abates aos 34 e 40 dias de idade para determinação dos rendimentos de carcaça e de cortes. De modo geral, a linhagem de crescimento rápido foi superior à de crescimento lento para as respostas de crescimento e rendimentos de carcaça e cortes. As aves responderam significativamente ao aumento no conteúdo proteico das rações, independentemente da linhagem utilizada para características de desempenho zootécnico; entretanto, as respostas de rendimento pós-abate não puderam ser relacionadas da mesma forma. A alternância de perfis proteicos aos 21 dias pode levar a conversões alimentares similares e, portanto, reduzir o custo de produção.

Palavras-chave: aminoácidos, carcaça, desempenho, linhagens, lisina digestível

\section{Introduction}

Commercially available broilers from diverse genetic backgrounds present variable growth rates, which reflect directly on the age needed to obtain desired body weight for marketing purposes. Olkowski (2007) stated that the use of high protein diets can reduce differences in the initial growth rate of broilers from different strain crosses. On the other hand, low nutrient density starter diets lead to a reduced body weight gain, whereas high protein at 
the beginning may result in better economic returns at processing age since the impact of nutrient intake in the first weeks is reduced when compared to higher intakes from later ages (Kidd et al., 2004).

Starter nutrition has been the target of many studies and scientific questioning since breast muscle is very sensitive to nutrient deficiency at this age (Halevy et al., 2000). However, the benefits in live performance obtained when broilers are fed high protein in pre-starter diets may not persist to 6 weeks of age (Pophal, 2004). Maintaining the gains of breast muscle obtained with the use of high protein pre-starters through the bird's life depends on nutritional programs used afterwards to the end of growth and until processing age. In practical terms, the modification of essential amino acid profiles is only possible for methionine, lysine and threonine, since the other amino acids are not commercially available and, therefore, cannot usually be supplemented.

Benefits in feed conversion obtained when growth is anticipated have stimulated the use of broiler strains with faster initial growth rate. However, metabolic mortality is accentuated in these birds, which has created management strategies to limit this initial growth. This has been done by limiting feed intake mainly using programs which restrict the number of lighting hours. However, low protein starter diets may represent a practical opportunity to reduce the initial growth without affecting the overall performance as long as growth compensation occurs further and the total cost of production is reduced (Kidd et al., 2005).

This study was conducted with the objective of evaluating the effects of feeding programs with different practical protein profiles on the performance and carcass yield of broilers from two strain crosses presently available on the market which have different initial growth rates.

\section{Material and Methods}

This study used 1,890 one day old broiler chickens from two strains with different initial growth rate (fast $=$ Cobb $\times$ Cobb 500; and slow $=$ Ross $\times$ Ross 308), obtained from a commercial hatchery and vaccinated for Marek disease and infectious bronchitis. Birds from both strains hatched simultaneously and were from the same breeder farm and breeders of similar ages (fast $=42$ and slow $=45$ weeks of age).

Birds were distributed in 70 boxes $\left(2.80 \mathrm{~m}^{2}\right)$ with rice hulls as litter. Temperature was within ranges to maintain animal comfort throughout the study using heaters, fans and foggers. Feed and water were provided ad libitum using manual feeders and nipple drinkers. Lighting was continuous in the first week and $16 \mathrm{H}$ afterwards.
Feeds were formulated with corn and soybean meal after total AA analyses. Digestibility coefficients (Rostagno et al., 2005) were applied to the AA values. Feeds were provided as mash, without antibiotic growth promoters. The feeding program had four phases: pre-starter (1 to $7 \mathrm{~d}$ ), starter (8 to $21 \mathrm{~d}$ ), grower (22 to $34 \mathrm{~d}$ ) and finisher (35 to $40 \mathrm{~d}$ ).

Increased levels of diets formulated on the ideal protein concept were studied. The diets were formulated on a practical basis and were similar in all the other nutrients and energy (Table 1). The ideal AA profile was established after contacts with the local industry in the South of Brazil. High and low ideal AA profiles were respectively 15\% above and below the industry values, which had digestible lysine as a starting point. Sulfur AA and threonine ratios to lysine were 75 and $65 \%$, respectively, whereas the other essential AA varied according to their contents in corn and soybean meal. After feed mixing, samples of each experimental diet were sent for AA analysis (Table 2). In the period from 1 to $21 \mathrm{~d}$, birds received diets with high, medium and low protein profiles. Treatments were then redistributed changing half of the birds fed the high diets to low and low to high. Birds fed the medium diet remained in the same treatment. Therefore, from 1 to $40 \mathrm{~d}$, ideal protein profiles were highhigh, high-low, medium-medium, low-high and low-low.

The broilers were group weighed within periods corresponding to the feeding phases when feed intake and feed conversion corrected for the weight of dead birds were also calculated. The broilers were processed at the experimental slaughter house at 34 and $40 \mathrm{~d}$. Six birds were randomly taken from each pen at each of these moments. The birds were electrically stunned after fasting for $8 \mathrm{H}$, and then manually slaughtered by cutting the jugular vein. The birds were the scalded at $60{ }^{\circ} \mathrm{C}$ for 1 minute, plucked and manually eviscerated. Carcasses were then immersed in ice for $3 \mathrm{H}$ at $2{ }^{\circ} \mathrm{C}$. Carcasses without viscera, necks and feet were hung to draw water excesses for 3 minutes and then weighed individually. Abdominal fat was removed manually and commercial cuts were performed by industry personnel allowing the calculation of relative weights of carcass to live weight and abdominal fat and commercial cuts to carcass weight.

The study was conducted using a randomized complete design in a factorial arrangement with 3 feeding programs $21 \mathrm{~d}$ of age. During this period, the diet with the Medium ideal profile had 14 replications, whereas the others had 28. After the end of the study, statistics were applied using a factorial arrangement using 5 feeding programs and 2 strain crosses consisting 10 treatments and 7 replications. Each box was the experimental unit and had 27 broilers at placement. Mortality and carcass data was submitted to arc 
Table 1 - Composition of experimental diets

\begin{tabular}{|c|c|c|c|c|c|c|c|c|c|c|c|c|}
\hline & \multicolumn{3}{|c|}{1 to 7 days } & \multicolumn{3}{|c|}{8 to 21 days } & \multicolumn{3}{|c|}{22 to 34 days } & \multicolumn{3}{|c|}{35 to 40 days } \\
\hline \multicolumn{13}{|l|}{ Ingredient, \% } \\
\hline Soybean meal & 42.12 & 36.08 & 30.41 & 37.45 & 34.56 & 31.84 & 34.1 & 28.6 & 24.65 & 31.59 & 26.68 & 22.59 \\
\hline Soybean fat & 3.69 & 2.67 & 1.71 & 5.56 & 4.68 & 4.02 & 6.20 & 5.02 & 4.12 & 6.44 & 5.33 & 4.37 \\
\hline Dicalcium phosphate & 1.84 & 1.87 & 1.91 & 1.67 & 1.71 & 1.76 & 1.62 & 1.66 & 1.68 & 1.39 & 1.41 & 1.44 \\
\hline DL-methionine, 99\% & 0.38 & 0.32 & 0.25 & 0.38 & 0.31 & 0.21 & 0.37 & 0.29 & 0.21 & 0.36 & 0.28 & 0.19 \\
\hline L-lysine $\mathrm{HCl}, 78 \%$ & 0.53 & 0.50 & 0.45 & 0.34 & 0.25 & 0.13 & 0.32 & 0.29 & 0.22 & 0.36 & 0.30 & 0.21 \\
\hline L-threonine, 98\% & 0.14 & 0.11 & 0.09 & 0.12 & 0.07 & - & 0.11 & 0.08 & 0.04 & 0.15 & 0.10 & 0.04 \\
\hline Salt & 0.33 & 0.34 & 0.34 & 0.34 & & & & & & & & \\
\hline Choline chloride, $60 \%$ & 0.05 & 0.07 & 0.09 & 0.06 & 0.07 & 0.08 & 0.04 & 0.06 & 0.08 & 0.05 & 0.06 & 0.07 \\
\hline Premix $^{1}$ & & 0.20 & & & 0.20 & & & 0.18 & & & 0.12 & \\
\hline \multicolumn{13}{|l|}{ Digestible amino acids } \\
\hline Methionine + cysteine (\%) & 1.05 & 0.94 & 0.83 & 1.01 & 0.89 & 0.78 & 0.93 & 0.82 & 0.71 & 0.90 & 0.79 & 0.68 \\
\hline Lysine (\%) & 1.40 & 1.25 & 1.10 & 1.34 & 1.19 & 1.04 & 1.24 & 1.09 & 0.94 & 1.20 & 1.05 & 0.90 \\
\hline Threonine (\%) & 0.91 & 0.81 & 0.72 & 0.87 & 0.77 & 0.68 & 0.81 & 0.71 & 0.61 & 0.78 & 0.68 & 0.59 \\
\hline Valine (\%) & 0.97 & 0.88 & 0.80 & 0.91 & 0.86 & 0.82 & 0.85 & 0.77 & 0.71 & 0.81 & 0.74 & 0.68 \\
\hline Isoleucine (\%) & 0.85 & 0.77 & 0.68 & 0.79 & 0.74 & 0.70 & 0.73 & 0.66 & 0.60 & 0.69 & 0.63 & 0.57 \\
\hline Arginine (\%) & 1.47 & 1.31 & 1.16 & 1.39 & 1.31 & 1.23 & 1.29 & 1.14 & 1.03 & 1.22 & 1.08 & 0.97 \\
\hline Tryptophan (\%) & 0.24 & 0.22 & 0.19 & 0.24 & 0.23 & 0.21 & 0.22 & 0.20 & 0.18 & 0.21 & 0.19 & 0.17 \\
\hline Сa (\%) & & 1.00 & & & 0.95 & & & 0.90 & & & 0.80 & \\
\hline Av P (\%) & & 0.50 & & & 0.47 & & & 0.67 & & & 0.62 & \\
\hline K (\%) & 0.99 & 0.90 & 0.81 & 0.93 & 0.94 & 0.83 & 0.86 & 0.77 & 0.71 & 0.82 & 0.74 & 0.67 \\
\hline $\mathrm{Na}(\%)$ & & 0.23 & & & 0.18 & & & 0.17 & & & 0.17 & \\
\hline
\end{tabular}

Table 2 - Amino acid analises of experimental diets ${ }^{1}$

\begin{tabular}{|c|c|c|c|c|c|c|c|c|c|c|c|c|}
\hline \multirow[t]{2}{*}{ Nutrient, \% } & \multicolumn{3}{|c|}{1 to 7 days } & \multicolumn{3}{|c|}{8 to 21 days } & \multicolumn{3}{|c|}{22 to 34 days } & \multicolumn{3}{|c|}{35 to 40 days } \\
\hline & High & Medium & Low & High & Medium & Low & High & Medium & Low & High & Medium & Low \\
\hline Crude protein & 26.20 & 23.50 & 21.45 & 21.45 & 20.97 & 20.02 & 23.21 & 21.41 & 18.25 & 21.84 & 20.39 & 19.30 \\
\hline Methionine+cystine & 1.134 & 1.046 & 0.924 & 0.954 & 0.917 & 0.896 & 1.020 & 0.888 & 0.720 & 0.990 & 0.851 & 0.668 \\
\hline Lysine & 1.775 & 1.514 & 1.287 & 1.475 & 1.397 & 1.319 & 1.477 & 1.376 & 1.038 & 1.462 & 1.300 & 0.889 \\
\hline Threonine & 1.114 & 0.966 & 0.857 & 1.053 & 0.954 & 0.859 & 0.978 & 0.909 & 0.886 & 0.956 & 0.849 & 0.771 \\
\hline Valine & 1.193 & 1.052 & 0.945 & 1.101 & 1.033 & 0.951 & 1.043 & 0.983 & 0.768 & 1.018 & 0.934 & 0.644 \\
\hline Isoleucine & 1.079 & 0.940 & 0.832 & 0.998 & 0.937 & 0.843 & 0.941 & 0.886 & 0.669 & 0.910 & 0.824 & 0.536 \\
\hline Arginine & 1.749 & 1.577 & 1.375 & 1.666 & 1.572 & 1.382 & 1.567 & 1.444 & 1.099 & 1.518 & 1.374 & 0.861 \\
\hline Histidine & 0.697 & 0.618 & 0.571 & 0.675 & 0.618 & 0.575 & 0.640 & 0.601 & 0.452 & 0.629 & 0.580 & 0.413 \\
\hline Leucine & 2.134 & 1.916 & 1.780 & 1.984 & 1.877 & 1.792 & 1.931 & 1.855 & 1.499 & 1.906 & 1.763 & 1.343 \\
\hline Phenylalanine & 1.271 & 1.125 & 1.014 & 1.207 & 1.100 & 1.014 & 1.126 & 1.068 & 0.821 & 1.105 & 1.004 & 0.677 \\
\hline Tyrosine & 0.878 & 0.759 & 0.698 & 0.815 & 0.765 & 0.691 & 0.753 & 0.713 & 0.565 & 0.748 & 0.688 & 0.473 \\
\hline
\end{tabular}

1 Processed at Ajinomoto Biolatina, São Paulo, Brasil.

sin transformation prior to the statistical analyses. Variables presenting statistical differences using the $\mathrm{F}$ test were separated using the Tukey test $(\mathrm{P} \leq 0.05)$.

\section{Results and Discussion}

Birds from the fast growing strain demonstrated increased body weight when compared to the slow growth strain throughout the study. In the periods from 1 to 7 and 8 to $21 \mathrm{~d}$, body weight was not different between the high and medium ideal protein levels, but it was reduced for the low protein level (Table 3). An interaction occurred for the body weight at $34 \mathrm{~d}$ (Table 4) when the body weight of the fast birds fed the high-high diets was higher than slow birds fed with all the other diets. Slow birds fed high-high diets 
presented higher body weight compared with birds from the same strain fed diets with low-high and low-low profiles, but were similar to those fed high-high and medium diets. At $40 \mathrm{~d}$, the fast birds presented greater body weight compared to the slow birds, regardless of the protein level used (Table 3). Similarly, at $40 \mathrm{~d}$, the high-high diets led to increased body weights when compared to all the other ideally balanced protein diets. Body weights obtained with the high-low protein profile were similar to the medium and low-high diets, but superior when compared to the low-low diets. The low-high protein profile, however, produced increased body weights at $40 \mathrm{~d}$ only when compared to those birds fed low-low diets.
Feed intake was different between genetic strains only in the periods between 1 to 7 and 8 to $21 \mathrm{~d}$ when the Fast birds presented higher intake compared to the Slow birds (Table 5). Between 1 and $7 \mathrm{~d}$, the diets with the high and medium protein profiles led to a similar feed intake, however, both were superior to the low protein diet. There was no difference between diets in the period of 8 to $21 \mathrm{~d}$. From 22 to $34 \mathrm{~d}$, the birds from the high-low diets showed a higher feed intake compared to those fed the high-high, medium, and low-high diets but similar to the low-low diets. The birds fed the low-high diets presented the lowest feed intake, whereas the other birds were similar. There were no differences in feed intake between treatments from 34 to 40

Table 3 - Body weight of male broilers from diverse genetic strains fed diets with graded increases in their ideally balanced protein profile

\begin{tabular}{|c|c|c|c|c|c|}
\hline Genetic strain & & 7 days & 21 days & 34 days & 40 days \\
\hline Fast & & $176 a$ & $980 a$ & $2,224 \mathrm{a}$ & $2,851 \mathrm{a}$ \\
\hline Slow & & $166 b$ & $924 b$ & $2,145 b$ & $2,725 b$ \\
\hline $\begin{array}{l}\text { Ideally balance } \\
1 \text { to } 21 \text { days }\end{array}$ & 22 to 40 days & & & & \\
\hline High & $\begin{array}{l}\text { High } \\
\text { Low }\end{array}$ & $175 a$ & $978 a$ & $\begin{array}{l}2,259 a \\
2,197 b\end{array}$ & $\begin{array}{l}2,907 a \\
2,779 b c\end{array}$ \\
\hline Medium & Medium & $173 a$ & $961 \mathrm{a}$ & $2,189 b c$ & $2,813 b$ \\
\hline Low & $\begin{array}{l}\text { High } \\
\text { Low }\end{array}$ & $165 b$ & $917 b$ & $\begin{array}{l}2,145 \mathrm{~cd} \\
2,133 \mathrm{~d}\end{array}$ & $\begin{array}{l}2,741 c \\
2,699 d\end{array}$ \\
\hline
\end{tabular}

a-d Means within the same column with different letters are different $(\mathrm{P}<0.05)$ using Tukey test.

Table 4 - Body weight interaction between genetic strain and ideally balanced protein profile in male broilers at 34 days of age

\begin{tabular}{lccc}
\hline Genetic strain & \multicolumn{2}{c}{ Ideal protein profile } & Body weight, g \\
\cline { 2 - 3 } & 1 to 21 days & 22 to 40 days & 34 days \\
\hline Fast & High & High & $2,273 \mathrm{a}$ \\
& & Low & $2,209 \mathrm{abc}$ \\
& Medium & Medium & $2,192 \mathrm{abc}$ \\
& Low & High & $2,176 \mathrm{abc}$ \\
Slow & & Low & $2,187 \mathrm{abc}$ \\
& High & High & $2,243 \mathrm{ab}$ \\
& & Low & $2,172 \mathrm{bc}$ \\
& Medium & Medium & $2,165 \mathrm{bc}$ \\
& Low & High & $2,129 c$ \\
& & Low & $2,087 \mathrm{c}$ \\
\hline
\end{tabular}

a-c Means within the same column with different letters are different $(\mathrm{P}<0.05)$ using Tukey test.

Table 5 - Feed intake of male broilers from diverse genetic strains fed diets with graded increases in their ideally balanced protein profile

\begin{tabular}{|c|c|c|c|c|c|c|}
\hline Genetic strain & & 1 to 7 days & 8 to 21 days & 22 to 34 days & 35 to 40 days & 1 to 40 days \\
\hline Fast & & $152 \mathrm{a}$ & $1,095 \mathrm{a}$ & 2,053 & 1,219 & 4,443 \\
\hline Slow & & $141 \mathrm{~b}$ & $1,057 b$ & 2,028 & 1,268 & 4,422 \\
\hline $\begin{array}{l}\text { Ideally balance } \\
1 \text { to } 21 \text { days }\end{array}$ & 22 to 40 days & & & & & \\
\hline High & $\begin{array}{l}\text { High } \\
\text { Low }\end{array}$ & $147 a$ & 1,083 & $\begin{array}{l}2,049 \mathrm{~b} \\
2,117 \mathrm{a}\end{array}$ & $\begin{array}{l}1,278 \\
1,248\end{array}$ & $\begin{array}{l}4,470 a \\
4,489 a\end{array}$ \\
\hline Medium & Medium & $148 \mathrm{a}$ & 1,066 & $2,034 b$ & 1,247 & 4,424ab \\
\hline Low & $\begin{array}{l}\text { High } \\
\text { Low }\end{array}$ & $143 b$ & 1,080 & $\begin{array}{l}1,950 \mathrm{c} \\
2,052 \mathrm{ab}\end{array}$ & $\begin{array}{l}1,194 \\
1,251 \\
\end{array}$ & $\begin{array}{l}4,303 \mathrm{~b} \\
4,475 \mathrm{a} \\
\end{array}$ \\
\hline
\end{tabular}

a-c Means within the same column with different letters are different $(\mathrm{P}<0.05)$ using Tukey test. 
d. However, from 1 to $40 \mathrm{~d}$, the highest feed intake was by birds of fast growth fed the low-low diets. The high-low diets provided to the slow growth birds was increased in comparison to the low-high diets fed to this same genetic strain. Birds fed diets with the other protein profiles were similar between each other from 1 to $40 \mathrm{~d}$ of age (Table 6).

Differences for feed conversion between genetic strains were observed from 8 to 21 and 1 to $40 \mathrm{~d}$, always in favor of the fast growth strain. The diets with high and medium protein profiles were better than the low protein diet to 21 d of age. Birds fed the high-high diets demonstrated improved feed conversion when compared to the others afterwards. As a result, the medium and low-high diets were similar between each other and the high-low and low-low presented the worst feed conversion (Table 7).

Mortality was not affected by genetic strain or diet at any moment during the study and, therefore, the data is not shown.

Carcass and commercial cut yields at $34 \mathrm{~d}$ were not affected by genetic strain, but presented differences due to diet. Backs had higher yields for birds fed low-low diets when compared to medium diets, which was in opposite presented by tenders yield (Table 8 ). There were interactions between factors for abdominal fat, breast fillets and tenders (Table 9).

Table 6 - Feed intake interaction between genetic strain and ideally balanced protein profile on male broilers from 1 to 40 days of age

\begin{tabular}{|c|c|c|c|}
\hline \multirow[t]{2}{*}{ Genetic strain } & \multicolumn{2}{|c|}{ Ideal protein profile } & \multirow{2}{*}{$\begin{array}{l}\text { Feed intake, } \mathrm{g} \\
1 \text { to } 40 \text { days }\end{array}$} \\
\hline & 1 to 21 days & 22 to 40 days & \\
\hline \multirow[t]{5}{*}{ Fast } & High & High & 4,483abc \\
\hline & & Low & 4,464abc \\
\hline & Medium & Medium & 4,381abc \\
\hline & Low & High & $4,314 \mathrm{bc}$ \\
\hline & & Low & $4,572 \mathrm{a}$ \\
\hline \multirow[t]{5}{*}{ Slow } & High & High & 4,457abc \\
\hline & & Low & $4,515 \mathrm{ab}$ \\
\hline & Medium & Medium & 4,466abc \\
\hline & Low & High & $4,292 \mathrm{c}$ \\
\hline & & Low & 4,378abc \\
\hline
\end{tabular}

a-c Means within the same column with different letters are different $(\mathrm{P}<0.05)$ using Tukey test.

Table 7 - Feed conversion of male broilers from diverse genetic strains fed diets with graded increases in their ideally balanced protein profile

\begin{tabular}{|c|c|c|c|c|c|c|}
\hline Genetic strain & & 1 to 7 days & 8 to 21 days & 22 to 34 days & 35 to 40 days & 1 to 40 days \\
\hline Fast & & 1.16 & $1.35 a$ & 1.66 & 1.77 & $1.59 \mathrm{a}$ \\
\hline Slow & & 1.17 & $1.41 b$ & 1.65 & 1.75 & $1.65 b$ \\
\hline $\begin{array}{l}\text { Ideally balance } \\
1 \text { to } 21 \text { days }\end{array}$ & 22 to 40 days & & & & & \\
\hline High & $\begin{array}{l}\text { High } \\
\text { Low }\end{array}$ & $1.14 \mathrm{a}$ & $1.34 \mathrm{a}$ & $\begin{array}{l}1.61 \mathrm{a} \\
1.74 \mathrm{c}\end{array}$ & $\begin{array}{l}1.71 \mathrm{a} \\
1.81 \mathrm{~b}\end{array}$ & $\begin{array}{l}1.57 \mathrm{a} \\
1.65 \mathrm{c}\end{array}$ \\
\hline Medium & Medium & $1.16 \mathrm{ab}$ & $1.35 a$ & $1.66 \mathrm{~b}$ & $1.79 b$ & $1.60 \mathrm{~b}$ \\
\hline Low & $\begin{array}{l}\text { High } \\
\text { Low }\end{array}$ & $1.19 b$ & $1.44 \mathrm{~b}$ & $\begin{array}{l}1.57 \mathrm{a} \\
1.70 \mathrm{bc}\end{array}$ & $\begin{array}{l}1.67 \mathrm{a} \\
1.80 \mathrm{~b}\end{array}$ & $\begin{array}{l}1.59 \mathrm{ab} \\
1.68 \mathrm{c}\end{array}$ \\
\hline
\end{tabular}

a-c Means within the same column with different letters are different $(\mathrm{P}<0.05)$ using Tukey test.

Table 8 - Carcass and commercial cut yields of male broilers from diverse genetic strains fed diets with graded increases in their ideally balanced protein profile at 34 days

\begin{tabular}{|c|c|c|c|c|c|c|c|c|c|}
\hline \multirow[t]{2}{*}{ Genetic strain } & & \multicolumn{6}{|c|}{ Yield, \% } & \multirow[b]{2}{*}{ Thighs } & \multirow[b]{2}{*}{ Wing } \\
\hline & & Carcass & Breast fillets & Tenders & Abdominal fat & Backs & Drumsticks & & \\
\hline Fast & & 74.8 & 21.2 & 4.38 & 2.24 & 25.74 & 13.8 & 19.4 & 10.9 \\
\hline Slow & & 75.2 & 20.8 & 4.38 & 2.29 & 26.60 & 14.0 & 19.2 & 11.0 \\
\hline \multicolumn{10}{|c|}{ Ideally balanced profile } \\
\hline \multirow[t]{2}{*}{ High } & High & 75.1 & $21.3 \mathrm{ab}$ & $4.42 \mathrm{ab}$ & $2.01 \mathrm{~b}$ & $26.08 \mathrm{ab}$ & 13.9 & 19.2 & 10.8 \\
\hline & Low & 74.7 & $21.1 \mathrm{ab}$ & 4.37abc & $2.48 \mathrm{a}$ & $26.07 \mathrm{ab}$ & 13.8 & 19.4 & 11.1 \\
\hline Medium & Medium & 75.0 & $21.4 \mathrm{a}$ & 4.53a & $1.96 \mathrm{~b}$ & $25.84 b$ & 13.8 & 19.4 & 11.0 \\
\hline \multirow[t]{2}{*}{ Low } & High & 75.1 & $20.4 b$ & $4.25 c$ & $2.55 a$ & $25.90 \mathrm{ab}$ & 14.0 & 19.3 & 11.0 \\
\hline & Low & 75.1 & $20.9 \mathrm{ab}$ & $4.33 \mathrm{bc}$ & $2.34 \mathrm{a}$ & $26.94 \mathrm{a}$ & 13.9 & 19.2 & 11.0 \\
\hline
\end{tabular}

a-c Means within the same column with different letters are different $(\mathrm{P}<0.05)$ using Tukey test. 
Table 9 - Carcass and commercial cut yield interaction between genetic strain and ideally balanced protein profile in male broilers at $34 \mathrm{~d}$

\begin{tabular}{|c|c|c|c|c|c|}
\hline \multirow[t]{2}{*}{ Genetic Strain } & \multicolumn{2}{|c|}{ Ideal protein profile } & \multicolumn{3}{|c|}{ Yield, \% } \\
\hline & 1 to 21 days & 22 to 40 days & Abdominal fat & Breast fillets & Tenders \\
\hline \multirow[t]{5}{*}{ Fast } & High & High & $1.90 \mathrm{bc}$ & $21.6 a$ & $4.52 \mathrm{ab}$ \\
\hline & & Low & 2.68a & 21.2ab & $4.29 \mathrm{ab}$ \\
\hline & Medium & Medium & $2.36 \mathrm{ab}$ & 21.1ab & $4.25 \mathrm{ab}$ \\
\hline & Low & High & $1.79 c$ & $21.4 \mathrm{a}$ & $4.54 \mathrm{a}$ \\
\hline & & Low & $2.47 a$ & 20.9ab & $4.31 \mathrm{ab}$ \\
\hline \multirow[t]{5}{*}{ Slow } & High & High & 2.11abc & 21.0ab & $4.31 \mathrm{ab}$ \\
\hline & & Low & $2.28 \mathrm{abc}$ & 21.1a & $4.45 \mathrm{ab}$ \\
\hline & Medium & Medium & 2.32abc & 20.7ab & $4.41 \mathrm{ab}$ \\
\hline & Low & High & 2.12abc & $21.5 \mathrm{a}$ & $4.52 \mathrm{ab}$ \\
\hline & & Low & $2.62 \mathrm{a}$ & $19.9 b$ & $4.18 b$ \\
\hline
\end{tabular}

a-c Means within the same column with different letters are different $(\mathrm{P}<0.05)$ using Tukey test.

Broilers from slow growth rate presented higher abdominal fat yield when compared to the fast growth broilers at $40 \mathrm{~d}$, which was the opposite to the breast yield. The protein profile of the diets had an influence on abdominal fat yield, which was reduced in birds fed highhigh and low-high diets, whereas those fed medium diets had an intermediate proportion of abdominal fat. Breast meat yield was lower on birds fed high-low and low-low diets, whereas thighs had a higher yield from birds fed high-high diets.

The AA profile resulting in formulated feeds is directly dependant on the ingredients used. All vegetable feeds based on corn and soybeans present methionine, lysine and threonine as the first three limiting AA (Berres et al., 2007). These are the only commercially available AA to be supplemented in broiler feeds to date (Vieira et al., 2006).

Presently, few alternatives exist between genetic strains for broiler chickens. The two mostly used are those used in the present study, which demonstrated marked differences in performance. Live performance and most of the carcass responses were better with the fast growth rate genetic strain. The final body weight in the present study resembled ranges which are dominant on the Brazilian market.
Recent research has shown that the limits for growth are not reached with the levels of AA currently used (Leeson et al., 1999; Dozier et al., 2006). Increasing diet nutrient density, especially AA, to levels above the usual improves the live performance, but also frequently the breast meat yield (Kidd et al., 2005). Even so, low density diets are still widely used because they have reduced cost. However, optimization of broiler meat production depends on the feed conversion and carcass yield, which can provide higher economic returns using more expensive diets (Kidd et al., 2004; Kidd et al., 2005; Dozier et al., 2006).

Increased AA concentration, especially lysine, was initially suggested in finisher diets in an attempt to improve breast meat yields of heavy broilers (Bilgili et al., 1992). However, increased concentrations of other essential AA in feeds provided immediately after hatching has been attractive since feed intake is very low in this period and therefore would have a reduced impact on the total feeding cost. Broiler responses to AA are also dependant on the genetic potential for growth and breast meat yield. This has been demonstrated in the past using several strain crosses (Moran et al., 1990; Bilgili et al., 1992). Kidd et al. (2004) demonstrated benefits of the increased

Table 10 - Carcass and commercial cut yields of male broilers from diverse genetic strains fed diets with graded increases in their ideally balanced protein profile at 40 days

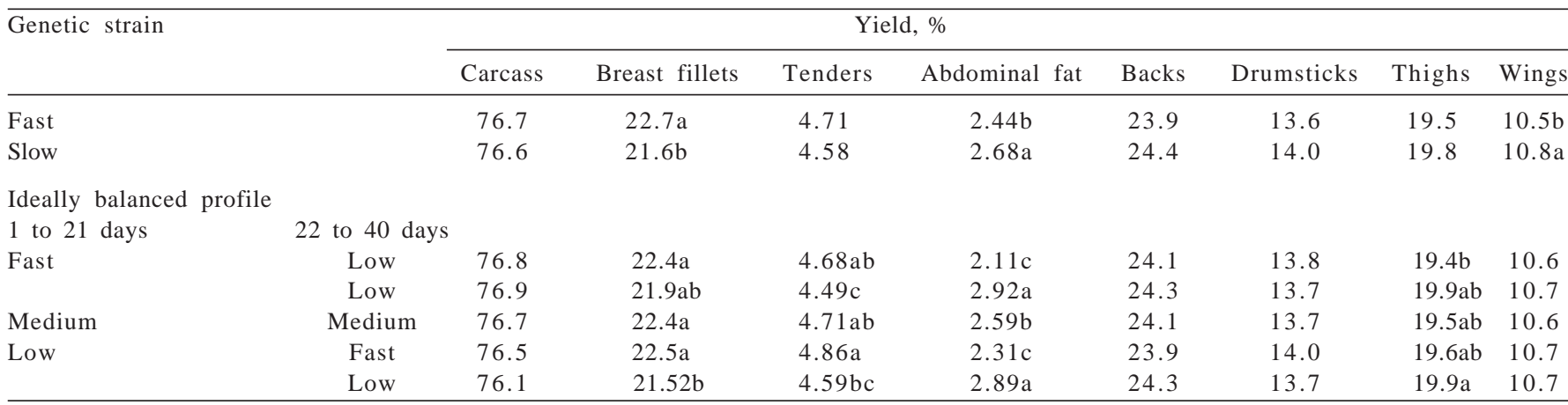

a-c Means within the same column with different letters are different $(\mathrm{P}<0.05)$ using Tukey test. 
AA concentrations in diets provided immediately after hatching. However, Pophal (2004) concluded that initial improvements do not last to marketing age once diets change to low density.

The supposition that broilers of high initial growth rates would increase feed intake as compensation when fed diets with low protein densities is not supported in theory when animals of similar body compositions are compared (Morris \& Njuru, 1990). In that study, after changing the protein profile, birds tended to immediately adapt with a higher intake to a low protein diet, but this did not last and at the end their feed intake was similar to those of birds fed high protein diets. Recommendations for the use of ideally balanced diets are currently available for all essential AA (Emmert \& Baker, 1997; Rostagno et al., 2005), but their practical application is still limited to the commercially available AA. In the present study, increasing the dietary protein profile led to improvements in feed conversion and reduced abdominal fat, even though the overall ideal AA balance could only be maintained for threonine. Moderate or high protein densities provided from 22 to $40 \mathrm{~d}$ improved breast meat yield regardless of the protein fed at the beginning. The benefits obtained in breast meat yield obtained with the increase in AA density were independent of the genetic strain utilized.

Improvements in live performance and breast meat yields have been continuous as genetic breeding programs are still providing yearly gains. Selection of genetic characteristics for improvement has been the target of research with broilers for a long time. However, these characteristics change as market demands also change and become the basis for broiler grower's choices. Lubritz (1997) found effects for sex and genetic strain on the length and width of the breast muscle and observed that the birds selected for growth rate also presented longer breast fillets than birds selected mainly for carcass yield. Pavan et al. (2003), on the other hand, studied three genetic strains and lysine levels in the diets and did not observe differences in breast meat yield. According to Kidd et al. (2005), high AA density diets frequently lead to economic benefits, even though their costs are higher. Results from the present study are in line with the findings in the literature which point to better economic returns when maximizing live performance and carcass yield. Low cost feeding programs generally with reduced AA density lead to poor live performance, especially when it comes to feed conversion, which in turn leads to comparative economic losses.

\section{Conclusions}

A genetic strain with fast initial growth rate had improved performance for all characteristics of economic interest when compared to one with a slower initial growth rate. Responses to dietary ideally balanced protein. However, occurred regardless of the genetic strain utilized. The use of diets with low AA density is not recommended since they lead to very poor performance. However, alternating diets with different AA profile may be a tool to optimize economic returns when birds are grown to $40 \mathrm{~d}$ of age.

\section{References}

BERRES, J.; VIEIRA, S.L.; CONEGLIAN, J.L.B. et al. Respostas de frangos de corte a aumentos graduais na relação entre treonina e lisina. Ciência Rural, v.37, n.2, p.510-517, 2007.

BILGILI, S.F.; MORAN JR., E.T.; ACAR, N. Strain-cross response of heavy male broilers to dietary lysine in the finisher feed: live performance and further-processing yields. Poultry Science, v.71, p.850-858, 1992.

DOZIER, W.A. III; GORDON, R.W.; ANDERSON, J. et al. Growth, meat yield, and economic responses of broilers provided threeand four-phase schedules formulated to moderate and high nutrient density during a fifty-six-day production period. Journal of Applied Poultry Research, v.15, p.312-325, 2006.

EMMERT, J.L.; BAKER, D.H. Use of the ideal protein concept for precision formulation of amino acid levels in broiler diets. Journal of Applied Poultry Research, v.6, p.462-470, 1997.

HALEVY, O.; GEYRA, A.; BARAK, M. et al. Early posthatch starvation decreases satellite cell proliferation and skeletal muscle growth in chicks. Journal of Nutrition, v.130, p.858-864, 2000.

KIDD, M.T.; MCDANIEL, C.D.; BRANTON, S.L. et al. Increasing amino acid density improves live performance and carcass yields of commercial broilers. Journal of Applied Poultry Research, v.13, p.593-604, 2004.

KIDD, M.T.; CORZO, A.; HOEHLER, D. et al. Broiler responsiveness (Ross $\times 708$ ) to diets varying in amino acid density. Poultry Science, v.84, p.1389-1396, 2005.

LEESON, S.; CASTON, L.J.; SUMMERS, J.D. et al. Performance of male broilers to 70 days when fed diets of varying nutrient density as mash or pellets. Journal of Applied Poultry Research, v.8, p.452-464, 1999.

LUBRITZ, S.L. A statistical model for white meat yield in broiler. Journal of Applied Poultry Research, v.6, n.3, p.253-259, 1997.

MORAN, E.T.; BILGILI, S.F. Processing losses, carcass quality and meat yields of broilers chickens receiving diets marginally deficient to adequate in lysine prior to marketing. Poultry Science, v.69, p.702-710, 1990.

MORRIS, T.R.; NJURU, D.M. Protein requirements of fastand slowgrowing chicks. British Poultry Science, v.31, p.803-809, 1990.

OLKOWSKI, A.A. Pathophysiology of heart failure in broiler chickens: structural, biochemical, and molecular characteristics. Poultry Science, v.86, p.999-1005, 2007.

PAVAN, A.C.; MENDES, A.A.; OLIVEIRA, E.G. et al. Efeito da linhagem e do nível de lisina da dieta sobre a qualidade da carne do peito de frangos de corte. Revista Brasileira de Zootecnia, v.32, n.6, p.1732-1736, 2003.

POPHAL, S. Características de crescimento de dois cruzamentos de frangos de corte recebendo dietas com 
diferentes níveis de lisina na primeira semana de vida. Porto Alegre: Universidade Federal do Rio Grande do Sul, 2004. 174f. Tese (Doutorado em Zootecnia) - Universidade Federal do Rio Grande do Sul.

ROSTAGNO, H.S.; ALBINO, L.F.T.; DONZELE, J.L. et al. Tabelas brasileiras para aves e suínos. Composição de alimentos e exigências nutricionais. 2.ed. Viçosa, MG: Universidade Federal de Viçosa, 2005. 186p.
STATISTICAL ANALYSIS SYSTEM - SAS. SAS/STAT User's guide: statistics release. Version 8.0. Cary: SAS Institute Inc., 2001. (CD-ROM).

VIEIRA, S.L.; OTT, R.P.; BERRES, J. et al. Effects of a mix of carbohydrases on live performance and carcass yield of broilers fed all vegetable diets based on corn and soybean meal. International Journal of Poultry Science, v.5, n.7, p.662-665, 2006. 